\title{
FORENSIC GENETICS AND GENOTYPING
}

Katarina Vitoševic ${ }^{1}$; Danijela Todorovic ${ }^{2}$; Zivana Slovic ${ }^{1}$; Radica Zivkovic-Zaric ${ }^{1}$ and Milos Todorovic ${ }^{1,3}$ ${ }^{1}$ Department of Anatomy and Forensic Medicine, Faculty of Medical Sciences, University of Kragujevac, Kragujevac, Serbia;

${ }^{2}$ Department of Human Genetics, Faculty of Medical Sciences, University of Kragujevac, Kragujevac, Serbia;

${ }^{3}$ Department of Forensic Medicine and Toxicology, Clinical Centre Kragujevac, Kragujevac, Serbia

\section{FORENZIČKA GENETIKA I GENOTIPIZACIJA}

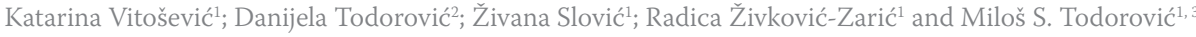 \\ Katadra za anatomiju i foreničku medicinu, Fakultet medicinskih nauka, Univerzitet u Kragujevcu, Kragujevac, Srbija \\ ${ }^{2}$ Katedra za humanu genetiku, Fakultet medicinskih nauka, Univerzitet u Kragujevcu, Kragujevac, Srbija \\ ${ }^{3}$ Katedra za forenzilčku medicinu i toksikologiju, Klinički centar Kragujevac, Kragujevac, Srbija
}

\section{ABSTRACT}

Forensic genetics represents a combination of molecular and population genetics. Personal identification and kinship analysis (e.g. paternity testing) are the two main subjects of forensic DNA analysis. Biological specimens from which DNA is isolated are blood, semen, saliva, tissues, bones, teeth, hairs. Genotyping has become a basis in the characterization offorensic biological evidence. It is performed using a variety of genetic markers, which are divided into two large groups: bi-allelic (single-nucleotide polymorphisms, SNP) and multi-allelic polymorphisms (variable number of tandem repeats, VNTR and short tandem repeats, STR). This review describes the purpose of genetic markers in forensic investigation and their limitations. The STR loci are currently the most informative genetic markers for identity testing, but in cases without a suspect SNP can predict offender's ancestry and phenotype traits such as skin, eyes and hair color. Nowadays, many countries worldwide have established forensic DNA databases based on autosomal short tandem repeats and other markers. In order for DNA profile database to be useful at a national or international level, it is essential to standardize genetic markers used in laboratories.

Keywords: Forensic genetics; Genotyping; Genetic markers; Databases

\section{SAŽETAK}

Forenzička genetika predstavlja spoj molekularne i populacione genetike. Identifikacija $i$ utvrdjivanje rodbinskih veza (npr. očinstva) su osnovni zadaci forenzičke DNK analize. Biološki materijali iz koga se izoluje DNK su krv, semena tečnost, pljuvačka, tkiva, kosti, zubi, dlake. Genotipizacija je postala osnov u karakterizaciji forenzičkih bioloških dokaza. Ona se izvodi pomoću različitih genetičkih markera koji su podeljeni u dve velike grupe: bialelski (pojedinačni nukleotidni poliorfizam, SNP) i multialelski polimorfizmi (varijabilni broj uzastopnih ponovaka, VNTR i kratki uzastopni ponovci, STR ). Ovaj revijski rad ukazuje na značaj genetičkih markera u forenzičkoj istrazi i ograničenja u njihovoj primeni. STR lokusi su trenutno najinformativniji genetički markeri u identifikacije, ali u slučajevima gde nema osumnjičenih SNP može da ukaže na poreklo prestupnika i fenotipske karakteristike, kao što su boja kože, očiju $i$ kose. U mnogim zemljama širom sveta uspostavljene su fonezičke DNK baze podataka koje se baziraju na autozomnim STR i drugim markerima. Da bi baze podataka o DNK profilu bile korisne na nacionalnom i inernacionalnom nivou neophodnoje da se standardizuju genetički markeri koji se koriste u laboratorijama.

Ključne reči: forenzička genetika, genotipizacija, genetički markeri, DNK baze podataka

\section{ABBREVIATIONS}

bp - base pairs

cfDNA - cell-free fetal DNA

CODIS - Combined DNA Index System

DNA - deoxyribonucleic acid

EDNAP - European DNA Profiling Group

ENFSI - European Network of Forensic Science Institute

ESS - European Standard Set

EU - European Union

FBI - Federal Burean of Investigation

HV1 - hyper variable region 1

HV2 - hyper variable region 2

MPS - Massively Parallel Sequencing
mRNA - messenger ribonucleic acid

mtDNA - mitochondrial DNA

NA - nucleic acid

PCR - polymorphism chain reaction

RNA - ribonucleic acid

RFLP - restriction fragment length polymorphism

SNP - single nucleotide polymorphism

SSR - simple sequence repeat

STADNAP - Standardization of DNA Profiling

STR - short tandem repeats

UV light - ultraviolet light

USA - United States of America

VNTR - variable number of tandem repeats

\section{sciendo}

UDK: 340.64:577.21

Ser J Exp Clin Res 2019; 20 (2): 75-86

DOI: 10.1515/SJECR-2016-0074
Corresponding author: Doc.dr Miloš Todorović Zmaj Jovina 30, 34000 Kragujevac, Tel: 062877 6761, Fax: 034306800 E-mail: mtodorovickg@gmail.com 


\section{INTRODUCTION}

Forensic genetics is an interdisciplinary science that uses techniques from statistics and computer science and connects them biology and law $(1,2)$. Typical contexts for forensic DNA analysis are disputes on kinship (e.g. paternity testing), corpse identification, forensic casework (criminal matters), missing person investigation and massfatality identification (e.g. terrorist attacks, airplane crash, tsunami disaster, war crimes) (2-4). Personal identification and relatedness to other individuals are the two main subjects of forensic DNA analysis (2).

Early molecular biology procedures were based on the analysis of protein polymorphisms (e.g. blood group) and phenotype polymorphisms (e.g. eyes and hair color). The discrimination potential of these systems is low compared to DNA polymorphisms $(3,5)$. Any two humans are $99,9 \%$ identical in their nucleotide sequences $(1,2,4)$. The remaining $0,1 \%$ indicates that, on average, for every 1,000 nucleotides there is one nucleotide that varies among people and defines different alleles of the corresponding gene, and for two randomly chosen individuals there are about 3 million bases differentiating haploid genomes (6). Polymorphisms in the DNA molecule are not uniformly distributed; in some regions of the genome they are densely packed. These hypervariable genetic loci are the source of forensic DNA typing and can be used to both differentiate and correlate individuals $(1,4)$. The forensic application of DNA typing methods over the past thirty years constitutes a major progression in the examination of biological evidence. With its remarkable sensitivity and power of discrimination, DNA analysis has become the most important in the fields of forensic science and forensic medicine (7).

\section{SOURCES OF DNA}

Biological specimens from whom DNA is isolated and typed are: blood and bloodstains, semen and seminal stains, saliva, tissues, organs, bones, teeth, hairs, fingernails, urine, and other body fluids (e.g. vaginal) (3, 7-10).

Blood samples provide large amounts of cells which contain DNA (11). It is possible to reproduce genetic profiles even from four-year-old dried blood stains (5). Many studies showed that blood was not a suitable substrate for personal identification in the case of blood transfusion, peripheral blood stem cells transplantation or bone marrow transplantation due to the presence of donor cells in the recipient blood cells $(12,13)$. Chaudhary et al. have shown that the saliva also contain donor cells (12). Other common biological sources for forensic DNA profiling in these cases are fingernails and hair follicles (12). However, some studies have shown donor chimerism (presence of donor cells in the recipient) in these sources, but very rarely (12).

Saliva is a potentially useful source of genomic DNA for genetic studies since it can be collected in a painless and non-invasive manner. The inhibitory substances are much lower and less complex in saliva (e.g. proteases from food particles, bacterial cells) (14) than in blood (e.g. heme, hemoglobin, lactoferin, immunoglobin G) $(15,16,17)$. Saliva transports exfoliated epithelial cells from buccal mucosa which contains DNA and the mean number of epithelial cells per $1 \mathrm{~mL}$ of saliva is about $4.3 \times 10^{5}$, which makes it a suitable source of genomic DNA $(8,11,18)$. Some studies have shown that DNA of perpetrator may be detected in the victim's oral cavity up to 1 hour after intense or constrained kissing $(8,10)$. Saliva can also be placed on human skin through kissing, biting, sucking and licking. Kenna et al. have reported that salivary DNA persists on the skin a minimum of $96 \mathrm{~h}$ (19). For example, it is possible to extract DNA from bite marks within this period, but amount of saliva deposited on the skin is usually very small in bite marks $(19,20)$. In addition, the concentration of salivary DNA varied from donor to donor and from day to day (19). Also many factors can cause DNA damage in saliva, such as: diet, brushing habits, eating habits, smoking, cancer in the oral cavity, fungal infection, etc. Problem with buccal cells is DNA contamination. Food particles often remain in the oral cavity which contaminates the exfoliated epithelial cells from buccal mucosa and leads to less yields of DNA and incorrect results (6).

The fingernail hyponychium can provide a valuable source of evidential material for investigation $(8,21)$. Traces of skin (especially if the victim scratched the perpetrator), body fluids and hairs may collect under the nails. The persistence of foreign DNA under the nails generally lasts up to $6 \mathrm{~h}$ (8). Cook and Dixon in their study detected foreign DNA in $13 \%$ of samples after $24 \mathrm{~h}(21)$.

Hairs from the victim or from the putative offender are frequently found at crime scenes. Isolation and analysis of DNA molecule from the hair root could provide the identification of the perpetrator. Hairs with intact root in the mitotically active anagen-growing phase mainly contain informative DNA profiles, while the inactive, naturally shed hairs in the telogen phase rarely yield informative DNA profiles. Unfortunately, $95 \%$ of the hairs found at a crime scene are inactive or in telogen phase (22).

Bones and teeth are available evidence for homicide committed several years ago or for homicides where the victim was not found promptly and they are often the only surviving material that can be tested especially in mass fatality incidents and mass graves (23). Bone and teeth samples protect DNA through their physical and/or chemical resistance to environmental degradation (23). Teeth with their anatomical location and morphological structure (enamel, dentine, pulp and cementum) provide unique protection to endogenous DNA from post-mortem degradation (24). The dental pulp also provides a rich source of DNA (25).

It should be noted that several factors affect the ability to obtain a DNA profile from biological samples: quantity of DNA, sample degradation and sample purity. The quantity and quality (purity and degradation) of DNA that can be extracted from biological sources are different and can vary 
as they are strongly influenced by the time after death and environmental conditions. The DNA quality really influences on genotyping and polymorphism chain reaction (PCR) amplification. Another common problem is the presence of inhibitors of DNA analysis and PCR amplification (26).

\section{Quantity}

In 1993, Decorte and Cassiman published that the conventional DNA typing needs at least 50 to $500 \mathrm{ng}$ of high molecular weight DNA (5). Nowadays, optimal amount of DNA is well defined and typically ranges from 100-200 pg to 2-3ng (1 ng is considered the optimum amount for most commercial kits) $(27,28)$. The quantity of DNA is different in different biological samples (Table 1). For comparison, total weight of DNA in one single cell is less than $7 \mathrm{pg}$ (1). The amount of DNA in each hair depends on the anatomic place of collection (e.g. head, beard, pubis) and varies between individuals. Also, the hair melanin is significant inhibitor of PCR DNA amplification, and therefore roots are preferable. Hair chemical treatments may furthermore decrease amount of DNA (8).

\section{Degradation}

All biological specimens are susceptible to degradation. For example, prolonged exposure of even a large blood stain to the environment can degrade the DNA and make it unsuitable for further analysis (7). Environmental sources of degradation are chemical (acids, bases, strong oxidizing agents), physical (heat and sunlight) and biological (bacteria and fungi) $(1,3)$. The most common source of degradation is biological in the form of mold and mildew. This is most commonly because moist materials are packed in a tightly sealed nylon bags which contributes to the development of microorganisms (1). In order to prevent DNA degradation, a forensic examiner must correctly select the type of material used for collection and storage (e.g. paper versus plastic bags) and ensure complete drying of the sample prior to packaging (8).

In cadavers, DNA degrades very quickly, which is the consequence of rapid bacterial increase, especially in those that are exposed to hot temperatures. At the same time, DNA in dead cells degrades under the influence of endonucleases and exonucleases $(5,26)$. The level of degradation also depends on the type of analyzed tissue (29). In comparison to soft tissues, hard tissues are greatly resistant to autolysis and decomposition caused by environmental factors. Therefore, bones, teeth and nails are the only source of DNA in some forensic cases $(3,29)$. Miloš et al. have shown that femur provided the best success rates while clavicle, ulna, and radius provided the lowest success rates (23). Maciejewska et al. have shown that if human remains are exposed to high temperature, samples of soft tissues of the highest weight (thickness) should be collected for the genetic analysis, because they give the best chance of successful identification (29).
Table 1. Quantity of DNA in diffrent biological samples $(1,7)$

\begin{tabular}{|c|c|}
\hline Type of sample & Amount of DNA \\
\hline Liquid blood & $30000 \mathrm{ng} / \mathrm{ml}$ \\
\hline Stain of blood & $200 \mathrm{ng} / \mathrm{cm}^{2}$ \\
\hline Liquid semen & $250000 \mathrm{ng} / \mathrm{ml}$ \\
\hline Postcoital vaginal swab & $0-3000 \mathrm{ng} / \mathrm{swab}$ \\
\hline Hair(with root) plucked & $1-750 \mathrm{ng} / \mathrm{root}$ \\
\hline Hair (with root) shed & $1-12 \mathrm{ng} / \mathrm{root}$ \\
\hline Liquid saliva & $5000 \mathrm{ng} / \mathrm{ml}$ \\
\hline Oral swab & $100-1500 \mathrm{ng} / \mathrm{swab}$ \\
\hline Urine & $1-20 \mathrm{ng} / \mathrm{ml}$ \\
\hline Bone & $3-10 \mathrm{ng} / \mathrm{mg}$ \\
\hline Tissue & $50-500 \mathrm{ng} / \mathrm{mg}$ \\
\hline
\end{tabular}

\section{Purity}

In biological specimens, besides the human traces, can also be found traces which originated from other organisms (plants and microorganisms), but the main sources of contamination originate from people. Contamination with microorganisms primarily depends on the way the samples are kept after collection (11). A distinction should be made between the so-called mixed sample and contaminated sample. Mixed sample contains DNA from two or more contributors, where the mixing occurred during the crime itself, usually with small amounts of DNA from potentially numerous contributors $(10,30)$. Contaminated sample contains DNA from the person who did not participate in the commission of the criminal offense and his or her DNA is deposited over the biological trace during the collection, storage and analysis. A sample may also be contaminated after it is collected from the crime scene and comes from the investigating officers, laboratory technicians and laboratory plastic ware. The issue of contamination is overcome by forming dedicated, specialized laboratories and by implementing protocols to reduce the risk of intra-laboratory contamination (28).

\section{GENOTYPING}

Genotyping has become a basis in the analysis of forensic biological evidence which allows analyses of an extensive choice of biological specimens (27). It is also known as DNA typing or DNA fingerprinting. It is called a "fingerprint" because it is very unlikely that any two people would have exactly the same DNA information, in the same way that it is very unlikely that any two people would have exactly the same physical fingerprint. Unlike clinical genetic research in which the result of DNA analysis itself is an information, in forensic genetics only by comparing DNA profiles obtained from one biological trace with the DNA profile from another biological trace we obtain the necessary information (1). The first method used for DNA fin- 
gerprinting is RFLP (restriction fragment length polymorphism), which detects the repeated sequences by defining a specific pattern to the variable number of tandem repeats, which forms the DNA fingerprint of a person. Using a special enzyme, called restriction endonuclease, that acts as a molecular scissors, DNA is cut into fragments on specific restriction sites. The chopped fragments have varying lengths. Gel electrophoresis is done to separate the cut fragments based on their size. A Southern blot (transferring the fragments to a nitrocellulose membrane) is then performed, and a radioactive probe is used to analyze the DNA. This RFLP analysis requires large quantities of DNA and requires long waiting time to obtain results (31). Nowadays DNA fingerprinting is based on PCR $(1,32)$. The remarkable sensitivity of the DNA typing assays permits even very small quantities of DNA to be genotyped (27). The regions of DNA that have most often been used in forensic analysis are located in non-coding genome regions (they are not genes) (33). The gene that codes for an exacting protein contributes to only $2-5 \%$ of DNA, whereas the remaining $95 \%$ are non-coding DNA (25). Therefore we mark them as markers (19). However, some of these noncoding markers are linked with visible traits (3). In forensic DNA analysis we used a variety of genetic markers and divided them into two large groups: multi-allelic polymorphisms (variable number of tandem repeats - VNTR and short tandem repeats - STR) and bi-allelic (single-nucleotide polymorphisms - SNP) $(1,3)$.

\section{Variable number of tandem repeats - VNTR}

In 1985, Alec Jeffreys have shown that highly polymorphic DNA segments (minisatellites or variable number of tandem repeats) are able to generate individual specific DNA fingerprints (34). The VNTRs contain repeated motif of $6-100$ bp $(3,10)$. The number of repeats varies from person to person. Because different alleles consist of different numbers of repeats, VNTR alleles can be identified by their lengths. The VNTR loci chosen for forensic use are on different chromosomes, or sometimes very distant on the same chromosome, so they are separately inherited (33). The VNTR loci are suitable for identification since they have a very large number of alleles, often a hundred or more $(1,3,33)$. The great number of alleles means that the number of possible genotypes is huge. For example, one VNTR in humans is a $17 \mathrm{bp}$ sequence of DNA repeated between 70 and 450 times in the genome, so that total number of base pairs at this locus could vary from 1190 to 7650 (2). Another advantage of VNTRs for genotyping is that none of the alleles is very common. Different alleles are much more comparable in frequency than multiple alleles of most genes. This is due to high mutation rate and the fact that most mutations increase or decrease the length of a VNTR by one or a few units (33). Due to high numbers of rare alleles, VNTR loci alone often lead to much higher exclusion (or inclusion) probabilities than single STR loci alone, which often have quite common and widespread al- leles $(1,2)$. The major limitation of VNTR analysis is that DNA has to be better preserved (1). In the early 1990s, forensic DNA analysis moved from markers which contain large core repeat units and large amplicon size to short tandem repeats (STRs), and the first available commercial kits for typing multiple STRs in a single reaction became available in the early 2000s (10). Nowadays the use of VNTR has been replaced by STR (short tandem repeats).

\section{Short tandem repeats - STR}

Today the power of forensic DNA analysis is in polymorphisms at the short tandem repeat (STR) loci and the number of STR loci used (35). STRs, known as microsatellites or simple sequence repeats (SSRs), contain repeated motif from1-5 for some authors, 2-7 or 2-10 nucleotides in length for others, that are repeated in tandem from approximately a half dozen to several dozen times $(25,36-$ 38 ). The small amplicon size of STRs (typically ranging from 100 to 500 bps in length) makes them suitable for the analysis of degraded DNA samples $(2,9,27,36,38,39)$. The STR loci are currently the most informative genetic markers for identity testing $(3,4,28,38)$. For example, the identity of the murdered Romanov family was confirmed using DNA extracted from bone fragments and amplified for 5 STR loci (HUMTH01, HUMVWA31, HUMF13A1, HUMFES/FPS, and HUMACTPB2), and amelogenin (40). Also forensic applications of STRs has allowed the reopening and solving old and forgotten cases and has also led to the exoneration of prisoners convicted through miscarriages of justice (32).

Limitation of using STRs is the high mutation rate of STR loci $\left(10^{-3}-10^{-5}\right)$, which makes them very informative, but also less stable (3). High mutational rates also lead to extensive polymorphism and increase the probability of isolated populations diverging rapidly at these STR loci, which makes them particularly useful in the study of population genetics (38).

Use of multiple STR loci in a single test enables a high power of discrimination without the use of large amount of DNA (e.g. 1 ng or less). PCR amplification of multiple STR loci at the same time is possible with different colored fluorescent dyes and different sized PCR products (36). This is an ideal technique for genotyping due to the probability that identical alleles in two individuals decrease with the increase in the number of polymorphic loci examined and also can save time and money, but difficulties may happen when coamplifying several loci. Multiplex PCR involves using a number of sets of PCR primers and allows targeting multiple locations throughout the genome. The problem is that primers for one locus can complex with those of other loci and completely inhibit the amplification. This effect may be avoided by leaving a specific STR locus under certain conditions (2).

Severely degraded DNA samples could contain only very short DNA template molecules (under $100 \mathrm{bp}$ ) making conventional STR typing (100-500 bp) unsuccessful. 
Damaged DNA templates (e.g. old bones, hair shafts) and minute amounts of cells occasionally lead to the elimination of single or, in the worst case, all alleles (2). In this case STR typing can be improved by moving the PCR primers closer to the STR repeat region, which reduces sizes of product while retaining the same information (3, 28, 36, 41). Thus, STR products reduced in lengths are marked as mini STR and if they are smaller than some of the fragmented DNA template molecules, genetic characterization of the sample may then be possible $(28,36)$. Butler have shown that the utility of these mini-STR assays has been confirmed in studies involving degraded bone samples and aged blood and saliva stains (36). Success rates in recovering information from severely degraded DNA samples are improved with mini-STR systems compared to conventional STR systems (36). Gill et al. described the acceptance of three new mini-STRs (D10S1248, D14S1434, D22S1045) into the European standard Interpol loci which now include 10 STR loci (42). Mulero et al. described the conversion of eight STRs (D7S820, D13S317, D16S539, D21S11, D2S1338, D18S51, CSF1PO, and FGA) into miniSTRs (41). The amplicon range for mini-STRs is 71-250 bp in length. Consequently, mini-STRs could be accommodated into one multiplex analysis. It would be better if all STR kits are reconfigured into mini-STR kits for routine analysis of forensic evidence. Only one attempt would be needed to obtain a DNA profile for limited-quantity samples. More efforts will continue to convert all current forensically relevant STRs into mini-STRs and to incorporate in one multiplex amplification kit (28).

\section{Single nucleotide polymorphisms - SNP}

Single nucleotide polymorphisms (SNPs), i.e. single base difference among two different individuals, are another type of genetic markers and have been considered as additional informative markers $(2,4)$. SNPs are base substitutions or insertions/deletions that occur at single positions in the genome (9). SNPs in humans occur on average every $1 / 2000$ bases (2).They have much smaller amplicons than those of mini-STRs, as short as 50-60 bp (3, 4, 28). This is very important when dealing with highly degraded DNA samples $(3,4,39)$.

Budowle and van Daal claim that SNPs are not the same and they categorized SNPs into categories: 1. identitytesting SNPs for individualization, 2. lineage-informative SNPs, sets of tightly-linked SNPs for identifying missing persons through kinship analyses, 3. ancestry-informative SNPs for establishing biogeography ancestry with high probability, 4. phenotype-informative SNPs for establishing phenotypic characteristics such as skin color, hair color, or eye color with high probability and 5. SNPs for pharmocogenetic investigations for determining the cause of death $(9,28)$. The information contained in the human genome may provide insights into personal characteristics such as ethnicity, physical and physiological characteristics (43). When there is no suspect, SNPs that describe phenotypic traits (such as pigmentation of skin, facial features, height, hair color and eye color) would enable a genetic prediction of appearance for investigative leads to identify the perpetrator or at a minimum help confirm or refute the more refractory eyewitness description $(28,43-45)$. Walsh et al. with six eye color-SNPs adjusted prediction of colors of the iris with accuracies of over $90 \%$ (46). Lui et al. suggested the used 9 SNPs (rs183671, rs12203592, rs10756819, rs1393350, rs17128291, rs12913832, rs2924567, rs4268748, rs6059655) as suitable markers for DNA prediction of skin color in Europeans and neighboring populations (44). The same phenotype-informative SNPs could be used to facilitate facial reconstructions for identifying missing persons (28). For example, in the 2004 Madrid train bombings source population of the suspects was concluded by using 34 ancestry-informative SNPs (43). In contrast to the personal information contained in STR markers, the resources regarding SNP markers are mostly population-oriented and can provide robust information on biogeographic ancestry that STRs can't provide due to their high global heterozygosity and greater mutation rate $(3,45)$.

Although SNPs are bi-allelic and consequently less polymorphic than multi-allelic STRs, they have two known advantages over STRs. The first advantage is that SNPs are more stable genetic markers with low mutation rates on the order $10^{-8}$ and so changeless likely over generations which is crucial concerning inheritance cases, missing per-

Table 2. Advantages and disadvantages of VNTR, STR and SNP genetic markers for DNA profiling $(1-4,9,27,28,33,36,38,39)$

\begin{tabular}{|c|c|c|}
\hline & Advantages & Diadvantages \\
\hline VNTR & $\begin{array}{l}\text { - Large number of allels }>100 \\
\text { - none of allels is very common } \\
\text { - high number of rare allels } \\
\text {-VNTR loci alone often lead } \\
\text { to much higher exclusion } \\
\text { (or inclusion) probabilities } \\
\text { than single STR loci alone }\end{array}$ & $\begin{array}{l}\text {-because the large amplicon } \\
\text { size of VNTRs DNA has to } \\
\text { be better preserved }\end{array}$ \\
\hline STR & $\begin{array}{l}\text {-small amplicon size makes } \\
\text { them suitable for for the } \\
\text { analysis of degraded DNA } \\
\text { samples } \\
\text {-high mutation rate lead to } \\
\text { extensive polymorphisms } \\
\text { which is useful in the study } \\
\text { of population genetics } \\
\text {-high power of discrimina- } \\
\text { tion without the use of large } \\
\text { amount of DNA }\end{array}$ & $\begin{array}{l}\text {-high mutation rate makes } \\
\text { them less stable }\end{array}$ \\
\hline SNP & $\begin{array}{l}\text {-smaller amlicon size than } \\
\text { sSTRs makes them suitable } \\
\text { for highly degraded DNA } \\
\text { samples } \\
\text {-ancestry and phenotype } \\
\text { SNPs can predict ethnicity } \\
\text { and phenotypic traits } \\
\text {-low mutation rates which is } \\
\text { helpful in inheritance cases } \\
\text { and missing person cases }\end{array}$ & $\begin{array}{l}\text {-because they are bi-allelic } \\
\text { and consequently less poly- } \\
\text { morphic } \\
\text {-individually less informative } \\
\text { than STRs } \\
\text {-large panels of SNPs } \\
\text { (50-100) are need for geno- } \\
\text { typing }\end{array}$ \\
\hline
\end{tabular}


son cases, and situations where no direct reference sample may be available $(3,4,9,28,39)$. The second advantage is that amplicon's size is less than $60 \mathrm{bp}$ in length (39).

However, SNP analysis also presents some limitations. It is generally accepted that SNPs are individually less informative than STRs $(4,9)$.The informativity may be increased by analyzing many unlinked SNPs, in order to achieve the level of discrimination typical for the 13 core STR loci, so large panels of SNPs (50-100) need to be genotyped (3, 4, 9, 39). Sanchez et al. have shown that the applied SNP typing multiplex with 52 SNPs in European populations provides a higher statistical power than 15 human identity STRs (39). Another limitation is that SNPs can provide only weak evidence of familial relationships or resolve mixtures of DNA from two or more individuals in a single sample, precisely because they are only bi-allelic $(3,9,45)$.

SNP markers offer a useful and important extension to a routine STR-based DNA typing $(3,4)$. SNPs give an almost unlimited source of human genome diversity for analyzing (3). An advantage of SNPs is that research and development at present is underway to improve analytical capabilities, possibly making large multiplex assays and complete automation possible. Consequently, the large battery of required SNPs can be used and can provide the power of discrimination currently obtained with STR kits. So a battery of SNPs with a high power of discrimination is desired (28). Some scientists go even further, taking into consideration that SNPs will replace STRs in forensic investigation (4).

Table 2 shows comparison of VNTR, STR and SNP genetic markers.

\section{MITOCHONDRIAL DNA}

Mitochondrial DNA (mtDNA) exists within cytoplasmic mitochondria as a separate small genome and contains a region (control region or D loop) which is composed of two hyper variable segments $(2,5,47)$. Two hyper variable segments of the control region, HV1 and HV2, are most variable between individuals and are therefore of special interest for forensic studies $(3,28)$. The principal advantage of mtDNA is that it is present in 500-2000 copies per cell $(3,5,43,47)$. Nuclear DNA, in spite of its great power of identification, is present only in cells with nucleus and in only two copies per cell (47). Many copies of mtDNA increase the chances that some copies of mtDNA will survive in highly degraded forensic samples and permit typing a great range of samples that would otherwise be unthinkable $(2,3,47)$. Such samples are highly degraded stains, bones, teeth, saliva, fingernails, and hair shafts $(3,28,47)$. As mentioned before, most of hairs founded at crime scene, are shed hairs and do not contain a root. However, the hair shafts still contain many copies of mtDNA (5). Another characteristic of mtDNA is that it is maternally inherited, so even distant maternal relative can provide a comparative reference sample with an expectation of a match (43,
$47,48)$. In identifying missing persons it is very important to compare mtDNA of unidentified remains with that of a possible maternal relative (25).

Due to lack of recombination, mtDNA can be analyzed as a single, highly informative multi-allelic locus (haplotype). A big advantage of using mtDNA is high mutation rate in the mitochondrial genome which causes high sequence variation. MtDNA is almost ten times more prone to mutation than nuclear DNA. Limitation of mtDNA is heteroplasmy or the presence of more than one mtDNA type in an individual, which is an uncommon characteristic of the mitochondrial genome and may complicate the interpretation (43).

\section{Y CHROMOSOME}

As $\mathrm{Y}$ chromosome is passed to the son from his father, analysis of markers on this chromosome helps in the identification of male lineages and inferring paternal genetic ancestry for judicial and investigative purposes $(25,49-51)$. Whereas these markers are transmitted as haplotypes in the same way as single locus alleles, they have the lack of recombination.

Nowadays there are many commercial kits available for Y-STR haplotyping which are useful in reconstructing paternal relationship (52). Given that Y-STRs markers have relatively low mutation rate of about $10^{-3}$ per locus per generation, they have proven useful for testing short to medium timescale paternal relationships. Other markers used for Y chromosomes are Y-SNPs and, with an average mutation rate of about $3 \times 10^{-8}$ per nucleotide per generation, they are suitable for studying distant relationships between male individuals and populations (50). Barra et al. have determined the male fetal Y-STR haplotype in maternal plasma during pregnancy and have estimated if the fetus and alleged father belong to the same paternal lineage (52). The main limitation is that it is only applied for mothers bearing a male fetus and its conclusion will be if alleged father and fetus belong to the same paternal lineage or not. Consequently, the test should not be performed in population with a high rate of endogamy (52).

Y-STRs are also used to resolve the male component of mixed DNA when a high female background is present (e.g. sexual assault cases) $(43,49,52)$. The vasectomized or naturally azoospermic rapist leaves no sperm, in such cases, Yspecific profiling is effective, even from samples with 1:4000 male:female DNA ratio (32). In the last few years the number of Y-STR markers for routine use in forensic and population genetics has grown significantly (49).

\section{CHROMOSOME}

The $\mathrm{X}$ chromosome is transmitted between both sexes in each generation, transferring different genetic information from uniparental genomes (53). Markers located on this chromosome have a particular inheritance pattern, be- 
cause women are dizygous and men are hemizygous (54). The X chromosome markers (X-STRs and X-SNPs) show higher efficiency parameters than autosomes in special kinship investigations (as well as incest cases), involving mainly female offspring $(48,53,54)$. The STRs on X chromosome can only be used in kinship analysis involving daughters, because there is no allele inherited by descent in a father-son relationship (54). Therefore, a growing number of scientists researching $\mathrm{X}$ markers uses them for studying the genetic structure of human populations, ancestry proportions in admixed populations and for forensic investigations (53).

\section{EXTRACELLULAR DNA AND RNA}

In 1978, Stroun et al. reported the presence of an RNA form in a nucleoprotein complex spontaneously released from human blood lymphocyte and frog auricle cultured cell systems (55). Extracellular nuclear acids (NAs) have been detected in a variety of biological specimens, including serum, plasma, saliva, urine, milk, bronchial lavage, cell culture supernatants. It is not defined how NAs are released from cells, whether by active secretion or as a result of apoptosis, or some combination of these mechanisms. Extracellular RNA may be protected from degradation by RNases, because they are being packaged into apoptotic bodies, integrated within nucleoprotein complexes with phospholipids and proteins. Analysis of extracellular mRNA profiling in forensic science has also been investigated (56). In 2003, using standard RT-PCR and gel electrophoresis, Juusola and Ballantyne reported that mRNAs specific for saliva and semen can be detected in stains as old as 10 weeks $(15,57)$. The mRNAs have been used for identification of human body fluids or tissues, which is very useful for forensic investigations to identify the origin of biological samples $(3,58)$. In 2005, Juusola and Ballantyne demonstrated the distinction of stains originating from different body fluids such as blood, semen, saliva and vaginal secretions (59). But the main part of the RNA preserved in salivary stains is cellular (15).

In 1997, Lo et al. detected "fetal" DNA in the plasma of pregnant women (60). So, the non-invasive prenatal testing is possible by detection of cell-free fetal DNA (cfDNA) in maternal circulation. The cfDNA originates from the placenta cells and apoptosis is the main mechanism of releasing it to the mother's circulation. Length of fetal DNA sequences in maternal plasma is mostly $150 \mathrm{bp}$ and is rarely longer than $250 \mathrm{bp}$, and their final disappearance from maternal circulation occurred after 1-2 days postpartum. Today, there are many situations where it would be desirable to do the noninvasive prenatal paternity testing by the analysis of the circulating cell-free fetal DNA (e.g. unclear paternity in case of women with more than one sexual partner who are unsure of the actual father) (52). Tumor-specific cell-free DNA has also been found in the circulation in many kinds of tumors. The presence of placental and tumor-specific cell-free RNA in plasma was also found (15).

\section{DNA DATABASE}

While the human genome contains thousands and thousands of STR markers, only a small core set of loci has been used in forensic DNA and human identity testing. Millions of STR profiles are formed worldwide every year by private laboratories, university and government performing different forms of human identity testing, including DNA data basing, forensic casework, kinship analysis, missing persons and mass disaster victim identification (36).

Currently, more than 60 countries worldwide have established forensic DNA databases based on STRs, and these databases continue to grow fast. Now, China has more than 27 million entries in its forensic database (43). Since 1997, The Federal Bureau of Investigation (FBI) uses a standard set of 13 specific STR loci, collectively referred to as Combined DNA Index System (CODIS) markers, and the sex-differentiating amelogenin locus AMEL-X/Y (1). The CODIS databank houses the largest number of DNA profiles compared to any other forensic DNA database $(10,28)$. In this database, the chances that more than one individual shares a 13-loci DNA profile are approximately one in one billion (10). The 13 routinely-used CODIS STR markers are: CSF1PO, FGA, THO1, TPOX, VWA, D3S1358, D5S818, D7S820, D8S1179, D13S317, D16S539, D18S51 and D21S11; and 15 markers are13 CODIS loci plus D2S1338 and D19S433 $(28,43)$. Although CODIS is used strictly in the USA and Canada, sometimes it is used to match probability in mass disasters outside USA. Thus, after Madrid terrorist attack in 2004, the CODIS database was used to match probabilities of 220 body remains against 98 reference samples, including 67 samples from relatives, representing 40 family groups and 27 antemortem direct references (2).

The forensic DNA databases of the most countries contain two types of profiles: profiles from convicted offenders and/or arrestee profiles (these profiles are from known sources and forensic profiles obtained from crime scenes (from unknown sources) $(3,61)$. Then CODIS utilizes computer software to automatically search its two indexes for matching DNA profiles and this technology is authorized by USA law (3).

In order for DNA profile database to be useful at a national or international level, it is essential to standardize the genetic markers used among laboratories (28). So, a number of organizations are currently involved in developing and promoting DNA databases across the European Union (EU). The European DNA Profiling Group (EDNAP) was established in 1988 with the aim of forming systematic procedures for data-sharing across the European community. The Standardization of DNA profiling in the EU (STADNAP) enhances usage of DNA profiling across the EU in order to help better detection of 'mobile serial offenders'. The European Network of Forensic Science Institutes (ENFSI) aims to undertake the standardization of forensic practices in support of policing across the whole 
of the EU (2). Recently, EU legislation has made all 28 members of the EU to participate in a network of national DNA databases (62).

To improve the discrimination power and the success in analyzing degraded DNA samples, the ENFSI and the EDNAP published in 2005 a list of three additional new miniSTR loci: D2S441, D10S1248 and D22S1045 and two additional polymorphic loci, D1S1656 and D12S391 (3). The FBI has suggested adding more autosomal STR loci to its present core set. The additional loci are mostly from those that the European system has chosen to supplement its core loci, assist with international data sharing and also increase discriminating power for missing person identifications. Also, one Y chromosome STR marker (DYS391) was added by the FBI into the new core loci, but the reason was to confirm amelogenin null values sometimes present in DNA typing. Many of Chinese crime laboratories have included Y-STRs in the standard protocol for sexual assault cases. However, because of the limitation in detection technology, only up to 25 to 30 autosomal STR and/or Y-STR loci can be multiplexed in a single kit and analyzed, which apparently indirectly limits the marker capacity of the DNA database to support forensic investigations. In the future, with Massively Parallel Sequencing (MPS) technologies it will be possible to type simultaneously all forensically-relevant autosomal STRs, Y STRs, X STRs, SNP and whole mitochondrial DNA genome sequences, comprising between 400-500 markers and much more (61). Addition of more loci increases discrimination power helps in missing persons' cases and makes a distinction between family members in closely related communities. In addition, with expanded locus overlap between numerous databases, international collaboration and data exchange would be easier. For that reason European and US forensic communities have taken steps toward these goals with proposal of the expanded CODIS core loci and acceptance of the European Standard Set (ESS) (63).

Since the early 1990s in the Western Balkan region, DNA analysis in forensic sciences has significantly increased. A large number of people that were buried in mass graves are identified by DNA typing. Forensic DNA testing in Serbia is performed in 6 laboratories. The use of DNA typing in criminal procedures in Serbia is regulated by the Criminal Procedure Act. This Act enables the district lawyer to order police to collect the buccal swab samples from the suspect, with or without his or her consent and requires the forensic pathologist to collect the DNA samples from unidentified bodies, and to collect and preserve samples of any biological traces obtained during autopsy (62).

DNA profiles are different from fingerprints (which are useful only for identification), because DNA can provide insights into many intimate aspects of a person and their families including predisposition to particular diseases and perhaps predispositions to certain behaviors (2). Expanded forensic DNA database will probably lead to the violation of a number of individual and civil rights (62). To defend individual and civil rights is to forbid the inclusion of genetic susceptibilities information in crime databases (2). For their SNP panel, Sanchez et al. pragmatically selected SNPs that were located at least $100 \mathrm{~kb}$ from any known gene, presumably to minimize the potential for perceived privacy risks (39). So the possible connection to a disease gene might be a criterion to consider about privacy. Prediction of physical traits limited to skin, eye, and hair color and possibly height and facial features is less likely to be considered a privacy matter (9).

\section{CONCLUSION}

Biological evidence for DNA studies is nowadays considered the most important evidence for legal proof in courts of law. DNA typing analysis can be performed on a large variety of materials, such as cigarette ends, tissues on a gun muzzle and on bullets, dismembered and decayed body parts, paraffin embedded tumor tissue, dirt and skin under fingernails, epithelia of an offender from the victim's neck after strangling, burned corpses, dried chewing gum, skeletal remains, body parts after mass disasters, skeletonized flood victims and human feces and urine. An inverse relation between the degradation and the length of DNA sequence that can be successfully and reproducibly analyzed influences the choice of DNA profiling technology and markers to be analyzed.

The STR analysis is still the most important and commonly-used genetic technique in forensic science. In complex cases of kinship analysis, severely degraded DNA or prediction of phenotype traits of offender's, SNP, Y-STRs, X-STRs and mtDNA could be used to complement autosomal STR typing. Multiplexing or the ability to simultaneously assessment several genetic markers in one analysis is the key to forensic testing. More simultaneously typed markers will reduce consumption of often limited precious forensic evidence.

The success of DNA typing in a police investigation can be greatly enhanced by storing DNA profiles in a central database. It is the quality of DNA database laws that makes DNA an effective investigative tool. Effective DNA databases are being constructed and numerous forensic cases solved today through generating STR profiles with a common set of genetic markers.

\section{ACKNOWLEDGEMENTS}

This work was supported by grant (project JP: 05/13) from the Faculty of Medical Sciences, University of Kragujevac, Serbia.

\section{REFERENCES}

1. Stojkovic O. (2008) Forenzicka genetika. In D.J. Dunjic I saradnici (Eds.) Ekspertizna medicina (pp 293-348). Beograd: Evropski centar za mir I razvoj Univerziteta za mir Ujedinjenih Nacija 
2. Bianchi L, Liò P. Forensic DNA and bioinformatics. Brief Bioinform. 2007;8(2): 117-28. [DOI: 10.1093/bib/bbm006].

3. Ziętkiewicz E, Witt M, Daca P et al. Current genetic methodologies in the identification of disaster victims and in forensic analysis. J Appl Genet. 2012;53(1): 4160. [DOI: 10.1007/s13353-011-0068-7].

4. Pontes ML, Fondevila M, Laréu MV, Medeiros R. SNP Markers as Additional Information to Resolve Complex Kinship Cases. Transfus Med Hemother. 2015;42(6): 385-388. [DOI: 10.1159/000440832].

5. Decorte R, Cassiman JJ. Forensic medicine and the polymerase chain reaction technique. J Med Genet. 1993;30(8): 625-633. [PMID:11387627].

6. Li WH, Sadler LA. Low nucleotide diversity in man. Genetics. 1991;129(2): 513-23. [PMID:1743489].

7. Lee HC, Ladd C. Preservation and Collection of Biological Evidence. Croat Med J. 2001;42(3): 225-8. [PMID:11387627].

8. Magalhães T, Dinis-Oliveira RJ, Silva B, Corte-Real F, Nuno Vieira D. Biological Evidence Management for DNA Analysis in Cases of Sexual Assault. Scientific World Journal. 2015;2015: 365674. [DOI: 10.1155/2015/365674].

9. Budowle B, van Daal A. Forensically relevant SNP classes. Biotechniques. 2008;44(5): 603-8, 610. [DOI: 10.2144/000112806].

10. Hu N, Cong B, Li S, Ma C, Fu L, Zhang X. Current developments in forensic interpretation of mixed DNA samples. Biomed Rep. 2014;2(3): 309-316. [DOI:10.3892/ br.2014.232].

11. Hansen TV, Simonsen MK, Nielsen FC, Hundrup YA. Collection of blood, saliva, and buccal cell samples in a pilot study on the Danish nurse cohort: comparison of the response rate and quality of genomic DNA. Cancer Epidemiol Biomarkers Prev. 2007;16(10): 2072-6. [DOI: 10.1158/1055-9965.EPI-07-0611].

12. Chaudhary G, Dogra TD, Raina A. Evaluation of blood, buccal swabs, and hair follicles for DNA profiling technique using STR markers. Croat Med J. 2015;56(3): 239-45. [DOI:10.3325/cmj.2015.56.511].

13. Li YT, Xie MK, Wu J. DNA profiling in peripheral blood, buccal swabs, hair follicles and semen from a patient following allogeneic hematopoietic stem cells transplantation. Biomed Rep. 2014;2(6): 804-808. [DOI:10.3892/br.2014.332].

14. Schrader C, Schielke A, Ellerbroek L, Johne R. PCR inhibitors - occurrence, properties and removal. J Appl Microbiol. 2012 Nov;113(5):1014-26. [DOI: 10.1111/j.1365-2672.2012.05384.x].

15. Zimmermann BG, Park NJ, Wong DT. Genomic targets in saliva. Ann N Y Acad Sci. 2007;1098: 184-91. [DOI:10.1196/annals.1384.002].

16. Kermekchiev MB, Kirilova LI, Vail EE, Barnes WM. Mutants of Taq DNA polymerase resistant to PCR inhibitors allow DNA amplification from whole blood and crude soil samples. Nucleic Acids Res. 2009 Apr;37(5):e40. [DOI: 10.1093/nar/gkn1055].
17. Al-Soud WA, Jönsson LJ, Râdström P. Identification and characterization of immunoglobulin $\mathrm{G}$ in blood as a major inhibitor of diagnostic PCR. J Clin Microbiol. 2000 Jan;38(1):345-50. [PMID:10618113].

18. Khare P, Raj V, Chandra S, Agarwal S. Quantitative and qualitative assessment of DNA extracted from saliva for its use in forensic identification. J Forensic Dent Sci. 2014;6(2): 81-5. [DOI: 10.4103/0975-1475.132529].

19. Kenna J, Smyth M, McKenna L, Dockery C, McDermott SD. The recovery and persistence of salivary DNA on human skin. J Forensics Sci. 2011;56: 170-75. [DOI: 10.1111/j.1556-4029.2010.01520.x]

20. Chávez-Briones ML, Hernández-Cortés R, JaramilloRangel G, Ortega-Martínez M. Relevance of sampling and DNA extraction techniques for the analysis of salivary evidence from bite marks: a case report. Genet Mol Res. 2015;14(3): 10165-71. [DOI: 10.4238/2015. August.21.23].

21. Cook O, Dixon L. The prevalence of mixed DNA profiles in fingernail samples taken from individuals in the general population. Forensic Sci Int Genet. 2007;1(1): 62-8. [DOI: 10.1016/j.fsigen.2006.10.009].

22. Bourguignon L, Hoste B, Boonen T, Vits K, Hubrecht F. A fluorescent microscopy-screening test for efficient STR-typing of telogen hair roots. Forensic Sci Int Genet. 2008;3: 27-31. [DOI: 10.1016/j.fsigen.2008.08.006].

23. Miloš A, Selmanović A, Smajlović L et al. Success rates of nuclear short tandem repeat typing from different skeletal elements. Croat Med J. 2007;48(4): 486-93. [PMID:17696303].

24. Higgins D, Rohrlach AB, Kaidonis J, Townsend G, Austin JJ. Differential nuclear and mitochondrial DNA preservation in post-mortem teeth with implications for forensic and ancient DNA studies. PLoS One. 2015;10(5): e0126935. [DOI: 10.1371/journal.pone.0126935].

25. Sakari SL, Jimson S, Masthan KM, Jacobina J. Role of DNA profiling in forensic odontology. J Pharm Bioallied Sci. 2015;7(1): 138-41. [DOI: 10.4103/09757406.155863].

26. Iwamura ES, Soares-Vieira JA, Muñoz DR. Human identification and analysis of DNA in bones. Rev Hosp Clin Fac Med Sao Paulo. 2004;59(6): 383-8. [http:// dx.doi.org/10.1590/S0041-87812004000600012].

27. Budowle B, Eisenberg AJ, van Daal A. Validity of low copy number typing and applications to forensic science. Croat Med J. 2009;50(3): 207-17. [DOI: 10.3325/ cmj.2009.50.207].

28. Budowle B, van Daal A. Extracting evidence from forensic DNA analyses: future molecular biology directions. Biotechniques. 2009;46(5): 339-40, 342-50. [DOI: 10.2144/000113136].

29. Maciejewska A, Wlodarczyk R, Pawlowski R. The influence of high temperature on the possibility of DNA typing in various human tissues. Folia Histochem Cytobiol. 2015;53(4): 322-332. [DOI: 10.5603/fhc. a2015.0029]. 
30. Hu N, Cong B, Gao T, Hu R, Chen Y, Tang H. Evaluation of parameters in mixed male DNA profiles for the Identifiler ${ }^{\circledR}$ multiplex system. Int J Mol Med. 2014;34(1): 43-52. [DOI: 10.3892/ijmm.2014.1779].

31. Girish K, Rahman FS, Tippu SR. Dental DNA fingerprinting in identification of human remains. J Forensic Dent Sci. 2010 Jul;2(2):63-8. [DOI: 10.4103/09751475.81284].

32. Jobling MA, Gill P. Encoded evidence: DNA in forensic analysis. Nat Rev Genet. 2004 Oct;5(10):739-51. [DOI: $10.1038 /$ nrg1455].

33. National Research Council (US) Committee on DNA Forensic Science: An Update. The Evaluation of Forensic DNA Evidence. Washington (DC): National Academies Press (US); 1996: 65-69. [DOI: 10.17226/5141].

34. Jeffreys AJ, Wilson V, Thein SL. Individual-specific 'fingerprints' of human DNA. Nature. 1985;316(6023): 769. [PMID:2989708].

35. Tracey M. Short Tandem Repeat-based Identification of Individuals and Parents. Croat Med J. 2001;42(3) 233-8. [PMID: 11387629].

36. John M. Butler. Short tandem repeat typing technologies used in human identity testing. Biotechniques. 2007;43(4):ii-v. [DOI: 10.2144/000112582].

37. Jovanovich S, Bogdan G, Belcinski R et al. Developmental validation of a fully integrated sample-to-profile rapid human identification system for processing single-source reference buccal samples. Forensic Sci Int Genet. 2015;16: 181-94. [DOI: 10.1016/j.fsigen.2014.12.004].

38. Foroughmand AM, Jari M, Kazeminezhad SR, Abdollahi A, Ahmadi L, Heidari M. Genetic analysis of two STR loci (VWA and TPOX) in the Iranian province of Khuzestan. Iran J Basic Med Sci. 2014;17(8): 583-7. [PMID:25422751].

39. Sanchez JJ, Phillips C, Børsting C et al. A multiplex assay with 52 single nucleotide polymorphisms for human identification. Electrophoresis. 2006;27(9): 171324. [DOI: 10.1002/elps.200500671].

40. Gill P, Ivanov PL, Kimpton C et al. Identification of the remains of the Romanov family by DNA analysis. Nat Genet. 1994;6(2): 130-5. [DOI:10.1038/ng0294-130].

41. Mulero JJ, Chang CW, Lagacé RE et al. Development and validation of the AmpFlSTR MiniFiler PCR Amplification Kit: a MiniSTR multiplex for the analysis of degraded and/or PCR inhibited DNA. J Forensic Sci. 2008;53(4): 838-52. [DOI: 10.1111/j.15564029.2008.00760.x]

42. Gill P, Fereday L, Morling N, Schneider PM. The evolution of DNA databases--recommendations for new European STR loci. Forensic Sci Int. 2006;156(23): 242-4. [DOI: http://dx.doi.org/10.1016/j. forsciint.2005.05.036].

43. Yang Y, Xie B, Yan J. Application of Next-generation Sequencing Technology in Forensic Science. Genomics Proteomics Bioinformatics. 2014;12(5): 190-7. [DOI: 10.1016/j.gpb.2014.09.001].
44. Liu F, Visser M, Duffy DL et al. Genetics of skin color variation in Europeans: genome-wide association studies with functional follow-up. Hum Genet. 2015;134(8): 823-35. [DOI: 10.1007/s00439-015-1559-0].

45. Kidd KK, Speed WC. Criteria for selecting microhaplotypes: mixture detection and deconvolution. Investig Genet. 2015;6: 1. [DOI: 10.1186/s13323014-0018-3].

46. Walsh S, Liu F, Ballantyne KN, van Oven M, Lao O, Kayser M. IrisPlex: a sensitive DNA tool for accurate prediction of blue and brown eye colour in the absence of ancestry information. Forensic Sci Int Genet. 2011;5(3): 170-80. [DOI: 10.1016/j.fsigen.2010.02.004].

47. Parsons TJ, Coble MD. Increasing the forensic discrimination of mitochondrial DNA testing through analysis of the entire mitochondrial DNA genome. Croat Med J. 2001;42(3): 304-9. [PMID:11387644].

48. Li L, Lin Y, Liu Y, Zhu R, Zhao Z, Que T. A case of false mother included with 46 autosomal STR markers. Investig Genet. 2015;6: 9. [DOI: 10.1186/s13323-0150026-y].

49. Westen AA, Kraaijenbrink T, Clarisse L et al. Analysis of 36 Y-STR marker units including a concordance study among 2085 Dutch males. Forensic Sci Int Genet. 2015;14: 174-81. [DOI: 10.1016/j.fsigen.2014.10.012].

50. Ballantyne KN, Ralf A, Aboukhalid R et al. Toward male individualization with rapidly mutating y-chromosomal short tandem repeats. Hum Mutat. 2014;35(8): 102132. [DOI: 10.1002/humu.22599].

51. Vieira TC, Gigonzac MA, Silva DM, Rodovalho RG, Santos GS, da Cruz AD. Y-STR haplotype diversity and population data for Central Brazil: implications for environmental forensics and paternity testing. Genet Mol Res. 2014;13(2): 3404-10. [DOI: 10.4238/2014. April.30.1].

52. Barra GB, Santa Rita TH, Chianca CF et al. Fetal male lineage determination by analysis of Y-chromosome STR haplotype in maternal plasma. Forensic Sci Int Genet. 2015;15: 105-10. [DOI: 10.1016/j.fsigen.2014.11.006].

53. Zhang S, Bian Y, Li L et al. Population genetic study of 34 X-Chromosome markers in 5 main ethnic groups of China. Sci Rep. 2015;5: 17711. [DOI: 10.1038/ srep17711].

54. Trindade-Filho A, Ferreira S, Oliveira SF. Impact of a chromosome X STR Decaplex in deficiency paternity cases. Genet Mol Biol. 2013;36(4): 507-10. [DOI:

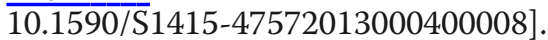

55. Stroun M, Anker P, Beljanski M et al. Presence of RNA in the nucleoprotein complex spontaneously relased by human lymphocytes and frog auricles in culture. Cancer res. 1978;38: 3546-54. [PMID: 688240].

56. O'Driscoll L. Extracellular nucleic acids and their potential as diagnostic, prognostic and predictive biomarkers. Anticancer Res. 2007;27(3A): 1257-65. [PMID:17593617]. 
57. Juusola J, Ballantyne J. Messenger RNA profiling: a prototype method to supplant conventional methods for body fluid identification. Forensic Sci Int. 2003;135(2): 85-96. [DOI:http://dx.doi.org/10.1016/ S0379-0738(03)00197-X].

58. Xu Y, Xie J, Cao Y et al. Development of highly sensitive and specific mRNA multiplex system (XCYR1) for forensic human body fluids and tissues identification. PLoS One. 2014;9(7): e100123. [DOI: 10.1371/journal. pone.0100123].

59. Juusola J, Ballantyne J. Multiplex mRNA profiling for the identification of body fluids. Forensic Sci Int. 2005;152(1): 1-12. [DOI:http://dx.doi.org/10.1016/j. forsciint.2005.02.020].

60. Lo YM, Corbetta N, Chamberlain PF et al. Presence of fetal DNA in maternal plasma and serum.
Lancet.1997;350(9076): 485-7. [ DOI: http://dx.doi. org/10.1016/S0140-6736(97)02174-0].

61. Hu N, Cong B, Li S, Ma C, Fu L, Zhang X. Current developments in forensic interpretation of mixed DNA samples. Biomed Rep. 2014;2(3): 309-316. [DOI:10.3892/ br.2014.232].

62. Marjanović D, Konjhodžić R, Butorac SS et al. Forensic DNA databases in Western Balkan region: retrospectives, perspectives, and initiatives. Croat Med J. 2011;52(3): 235-44. [DOI:10.3325/cmj.2011.52.235].

63. Oostdik K, Lenz K, Nye J et al. Developmental validation of the PowerPlex $\left({ }^{\circ}\right)$ Fusion System for analysis of casework and reference samples: A 24-locus multiplex for new database standards. Forensic Sci Int Genet. 2014;12: 69-76. [DOI: 10.1016/j.fsigen.2014.04.013]. 
$\$$ sciendo 